\title{
Sustainability and Supply Chain Empowerment: The Lavazza Case*
}

\author{
Mario Cerutti ${ }^{* *}$, Giacomo Büchi ${ }^{* * *}$
}

\begin{abstract}
Integrated and systemic Corporate Social Responsibility is placed at the heart of business, where concepts like social, environmental and economic sustainability need to become intrinsic characterizations of the business and the decision-making process, by adopting a multi-stakeholder perspective, within the redesign of strategic priorities. Accordingly, this change of mentality imposes redefinition of relationships with stakeholders, changes in the organizational structure, modifications of management responsibilities and, reconfiguration of roles. Lavazza SpA could be considered as a leading case, since every sustainable action is focused on business and its players.
\end{abstract}

Keyword: Sustainability; Coffee Market; Lavazza Foundation; Supply Chain Empowerment; Family Business

\section{Coffee Industry: The Relevance of Critical Stakeholders' Empowerment}

Coffee industry presents peculiar characterizations and complexity in the configuration of relationships among companies and their stakeholders. It is a business with a complex, long and "specific" value chain, which for many years has been exposed to critics as far as its sustainability and responsibility are concerned, especially in regard to its strong link to some of the poorest areas of the world, where coffee is being cultivated (Potts, 2003; Blowfield et al., 2010; Valkila et al., 2010).

The value chain sees three major actors involved from its upper end to the roaster: the producers, who are often smallholder local farmers and family business owners mainly responsible for the extraction of coffee beans and for the quality of the finished product; groups of local traders (usually not organized) who buy coffee from small growers; exporters who collect what produced and export (Upendranadh and Subbaiah, 2012).

It is to underline that there are roughly 25 million people who base their livelihood on coffee production (Watson and Achinelli, 2008) and grow almost $70 \%$ of the coffee beans (Oxfam, 2001; 2003) and, more generally, approximately 500 million family farmers around the world producing $80 \%$ of the food globally

\footnotetext{
** Invited Article

** Chief Sustainability and Institutional Relations Officer. Lavazza SpA (mario.certutti@lavazza.com)

Lavazza Foundation Board member (giacomo.buchi@unito.it)
} 
consumed (Graeub et al., 2015). Moreover, coffee producers are, in most cases, small-scale farmers who by necessity frequently rely on local traders. Furthermore they have to do with instable markets and climate changes and all these elements can compromise their whole activity (Cleland, 2010), because of their dimensions.

Thus, sustaining smallholder farmers towards governments, markets and risks connected to climate change through empowerment projects is a sort of responsibility which some roasters and coffee companies feel to have, even because this can lead to an improved green coffee been quality and a better trading. Methods of empowerment are various with different impact on firms' activities and largely depend on the extent to which the whole organization implements innovative and integrated paradigms of the so-called Corporate Social Responsibility (CSR), which is to define as "a concept whereby companies integrate social and environmental concerns in their business operations and in their interaction with their stakeholders on a voluntary basis" (UE Green Paper, 2001) and which, during the years, has shifted, for firms, its name in the more comprehensive term "sustainability".

Literature suggests that one of the main reasons causing greater complexity in company-stakeholder relationship derives from the asymmetric and imperfect information at stakeholders' disposal (Pezet \& Casalegno, 2017; Brondoni, 2014), throughout the whole coffee value chain (Bush, 2012; Guash et al., 2007; Potts, 2003). It is argued that imperfect information can often make players take unsustainable decisions (Potts, 2003) and, consequently, augment the disparities in market power.

Critical stakeholders empowerment in coffee industry has to do with practices redefining the business model and obtain small farmers participation in the public debate (Prato \& Longo, 2012), improve operations and their inclusion into the business model and, will therefore be crucial to building long-term sustainability of the business (Potts, 2003). The present paper goes beyond the act of integrating CSR in marketing strategies, even though this is effective above all for large companies (Benyoussef et al., 2017). This is about embedding CSR elements in every firm relation along with the supply chain and its critical stakeholder (Mosca \& Civera, 2017).

\section{Beyond Corporate Social Responsibility through the Giuseppe e Pericle Lavazza Foundation}

The first relevant factor to be underlined is that the history of Lavazza's business is strongly related, since its very beginning, to a tradition of high involvement and commitment to its reference territory and its stakeholders that the company have always regarded to as partners.

Those have been crucial for the development of tangible solutions - including processes and products - addressed to increase the value of any strategy and activity, as well as the social and economic value of the communities in which it operates. 
In 1935 Luigi Lavazza, the Lavazza founder, went to South America to personally see coffee territories, coffee farmers and their lives. During his trip he discovered a shocking reality: whole crops of unsold coffee destroyed. This experience could deeply affect his way to business, as well as the legacy he left to his family and his employees and, from that moment on, Lavazza has always had a peculiar attention to social environmental and economical factors affecting the places in which coffee grows. This concept has raised since today as "integrated sustainability" driven by a life cycle thinking model, which allows value creation along the entire supply chain, with the constant aim of continuous improvement.

It is probably thanks to this intrinsic philosophy that Lavazza holds a position as leader in Italy and can, nowadays, count on 1.895,7 million euros revenues for the year 2016 with increasing sales from 2015.

Recognizing its impacts throughout the whole value chain led the company to prioritize some activities towards certain categories of stakeholders that represent key resources for products' quality and, ultimately, success: the local farmers involved in the extraction of coffee beans, located in Brazil, Costa Rica, Dominican Republic, El Salvador, Ethiopia, Guatemala, Haiti, Honduras, India, Indonesia, Peru, Uganda, Vietnam and, Tanzania.

In the logic of active cooperation with those key stakeholders, the company started in 2004 a series of strategic interventions (pilot projects) through the Giuseppe e Pericle Lavazza Foundation and working closely with NGOs operating locally, with the aim of promoting, developing and coordinating activities aimed at improving the work and the private life of families of smallholders, and ultimately contributing to augment their environmental sustainable approach towards coffee cultivation and its processing. Other strategic projects, like "Coffee and Climate" and "Tierra" seek, respectively, to minimize the effects of climate change and improving life standards and product quality by providing local farmers with innovative tools and knowledge for better producing, trading and being real competitive and autonomous.

To efficiently coordinate and develop the above-mentioned projects, in 2004 the Company established the Fondazione Giuseppe e Pericle Onlus, with the aim of promoting and funding ideas for developing and empowering coffee local communities. The main goal, of course, is strategic, because the final will is to protect the raw material representing both the supply and value chains starting point. As stated in 2015 Lavazza Sustainability report, the Foundation board consists in five members, including two Lavazza family members and three University full professors.

Furthermore, it is to underline that the current chief of Sustainability in Lavazza is also the Secretary of the Foundation. The philosophy that has always inspired the Foundation has begun with the promotion of sustainable projects over time, thanks to strategic partnerships with public and private actors. This is the reason why the Foundation selects, case by case, the most suitable partners, to assure effective and lasting results. A pre-competitive approach that involves other actors of the sectorboth organizations and firms - at different partnership levels: the pilot projects design and their development, the long period commitment, the project governance, the technical and rural components. Developed projects have a twofold aim: 
- to develop quality and quantity of coffee produced the production by applying different farming practices and the so called "good agricultural practices" (GAP);

- $\quad$ to promote the entrepreneurship, even though the farmers to whom projects are addressed do not represent the Lavazza supply chain upper end level.

Many other elements can be added to these aims, as: the gender equality, the food security, the reforestation, the minimization of the environmental impacts communing from the coffee production. Furthermore, in 2014 the Collaboration with the United Nations Conference on Trade and Development has started with the aim of developing entrepreneurial skills for small farmers, who deliver the $75 \%$ of the world coffee production.

\section{Luigi Lavazza SpA and Giuseppe e Pericle Lavazza Foundation: Which Governance?}

The family governance soundness supports an industrial approach directed to a long period value creation.

The Group consists in 30 companies, which are directly or indirectly managed by the Luigi Lavazza SpA (which is located in Turin) and the activity of the foreign subsidiaries mainly concerns in products and coffee machines distribution and commercialization. With its own action, Lavazza is present in 90 Countries in the world, over 3000 collaborators and 50 trainings centres. In 2016, the Group brands are: Lavazza, Carte Noir and Merrild (both from March 2016), Kicking Horse (2017) Eraclea (2010) Whittington Tea (2010).

For over 120 years the Lavazza Group business model has been driven by a synergy between its value always (shared with internal and external stakeholders) and financial viability and this is shown by the efforts Lavazza puts in pursing sustainable results. Giving some data about that, it is useful to consider the 2016 Lavazza Sustainability report, in which information about all the sustainability investments are available. In the three years period 2014-2016 investments amounted to 17.7 million Euros and they were addressed to researches over coffee quality, consumer health and safety, responsible management of the supply chain, Lavazza Foundation projects and initiatives, donations, sustainable coffee pod redesign, environmental actions, a more sustainable packaging.

Talking about the governance, it is interesting to understand how the Group is linked together with the Foundation, since both their aims are increasingly converging. In 2016 a new approach to the Sustainability has arisen, underlining a deeper link between the Company itself and its Foundation. As already stated, the Foundation has its own Secretary who has always worked inside the Group, before as the supply chain Manager, then as green coffee and corporate relations Partner and, from 2016, as Chief of Sustainability and Institutional Relations.

This last position has a double meaning: first, it highlights how fundamental the sustainability has become for Lavazza, getting one of the most strategic and transversal firm functions. The so-called Corporate Social Responsibility at the very beginning (2011) was established inside the Group as a set of coordinated 
actions under the umbrella of the Human Resource function, with a CSR Manager, whose first initiatives output is represented by the 2014 Sustainability Report editing: this could mark the beginning of the Lavazza "sustainable revolution". Second, it underlines a deeper relation between the Foundation and the Group: all the philanthropic actions are focused on the coffee business, they are engaged to empower the upper-end level of the supply chain, to protect the coffee plants from the climate change, to make coffee smallholder farmers more conscious of how important is their role: for Lavazza, it is not about croppers, it is about entrepreneurs.

Since when we talk about Lavazza, we talk about a family business it is important to examine which is the role played by the Lavazza family; Lavazza family members are entirely involved in the coffee business, but it is fundamental to underline that during the last years the family has preferred to delegate the strategic and managerial functions to external managers, able to make decisions without mixing business and family relationships.

The Lavazza family is deeply involved in the definition of the company strategy. By sharing the most important decisions with the management.

At the same time, the family valiantly works inside the Group (they all are Board of Directors members and two of them are part of the Foundation board) to ensure that both the business and the philanthropy actions are carried on by following the mission principles and the values which have always been present in what is possible to call the "Lavazza way".

\section{Empowerment and Sustainable Projects First Outputs}

In keeping with its business driving values, Lavazza's element of differentiation can be seen its capacity to coordinating various players in the coffee chain in order to create synergies and strengthen the impact of each project (Coffee Barometer, 2014).

In 2011 the company decides strategically to go beyond the responsibility of its business on the environment, community, customers and stakeholders as a whole and to develop a formal Company Stakeholder Responsibility, based on the awareness towards all the aspects of the business and its impacts throughout the value chain, by legitimating the power of local smallholders and cooperate with them towards more effective and efficient social and economic outputs. Thus Corporate Social Responsibility was set up formally as a business function within the organization through the identification of a CSR Manager with a specific duty: to structure the CSR in order to involve the entire organization with its business functions and embed the value chain and the partners primarily. From a strategic activity, CSR has evolved to an integrated and systemic function, in a logic of cooperation, partnership development and Life cycle assessment, to focus on the value creation for the business and the community. This awareness of the topic could lead Lavazza Managers to the concept of Sustainability, which for Lavazza is not a goal; instead, it represents a starting point of a virtuous circle, which can lead 
to savings - thanks to processes innovation - and larger investments, to converge on further innovations.

Sustainability projects have been defined by Giuseppe Lavazza as "creative, characterized by scalability, glocal, circular and, a property of the whole system" (Nembri, 2015).

What is peculiar to report is how the implementation of such sustainability contributes to activate projects of key stakeholders empowerment in the geographical areas reported above. Especially, given that coffee industry sees a dramatic increase in consumption (every 10 years about 20 million more coffee bags are required by the market), sustainable and responsible practices become for players even more challengeable.

In order to meet this trend effectively and efficiently, among various players, Lavazza appears to be highly involved in responding with the increase of productivity rather than other unsustainable choices (as deforestation or lands overexploitation, without concerns towards local communities). It is clear that sustainability is primarily based on economical advantages that benefit the firm and the local farmers at the same time, as a win-win integrated relation. Without providing smallholders and local farmer with an economic autonomy first, it is, in fact, very difficult to refer to environmental and social sustainability. Those concerns come once key stakeholders are empowered to take active part in the economic transactions.

Within sustainability, every pursued empowerment project appears to be characterized by a stronger ownership and engagement of the communities through partnership, meaning that only actual needs referring to work and smallholders' life conditions are considered as priorities and pursued in cooperation. Moreover, projects are set up according to the institutional peculiarities and relations with governments of each country.

It is on the upper end of the value chain that the biggest effort for empowerment and engagement appear.

Concretely, the main projects of empowerment vary from the most renown such as Tierra and Coffee and Climate to others carried out in Brasil, Uganda, Ethiopia, Tanzania, Haiti and Dominican Republic, India, Vietnam and Indonesia. The table below shows the projects and the 2015 UN Sustainable Development Goals Lavazza could reach through.

The basis for local farmers empowerment is the exchange of information and sharing. Farmer Fields School, for instance, gathers together groups of 20 farmers in one's land at a time with the aim of sharing good practices, production issues and find sustainable common solutions. The objective is always to have key stakeholders activating a system characterized by awareness, access to training and cooperation.

The project launched in India in 2013 created an organization for small producers named MAS (in which Lavazza has no financial participation) with the objective of providing services for members and third parties relevant to the business enhancement such as land analysis, fertilizers analysis, humidity control and, product quality assessment. Advisory and support on specific characteristics of the 
land and elements of quality are necessary for local farmers to strive for value creation.

Lavazza, as business incubator, supported the creation of the organizational structure, provided training to human resources and advised on the mechanism of governance, in order to allow greater autonomy of the organization.

One of the key challenges of sustainability stays in the measurement of impacts and performances for empowerment projects on local farmers and territory. In order to tackle this, Lavazza adopts two approaches: first of all, the firm implemented a system to measure the direct impacts on local families of farmers not only in terms of increased revenues by coffee production but, also, in terms of increased domestic expenditures addressed to the benefit of the family itself. Secondly, Key Performance Indicators (KPI) are assessed in order to underline competitive approaches for each project that can be replicated to others, in other lands or countries.

Favouring cooperation, enhancement of entrepreneurship capital (providing finance, marketing and, operation expertise) and, heritage sharing means for Lavazza activating strong advocacy and institutional communication campaigns in favour of key local stakeholders and spread it throughout the whole value chain.

These philanthropy actions, which can be seen as strategic for the business itself, have changed their focus in the last year and this is witnessed by the way through which the annual Lavazza calendar has been developed during the years.

The Lavazza calendar, which has seen its first edition in 1993 as benchmark of creative communication, in 2015 has shifted its main goal, beginning to represent those who are the real coffee market leading actors: the coffee farmers, their territory and their families. These people are seen, in every calendar, as contemporary heroes, since there are not only responsible for the quality of the raw material, but because they everyday strive for protecting their business, their environment, their traditions, even though this means to face various threats. This is the main message coming from the 2015 calendar, titled the Earth Defenders, in which the famous photographer Steve McCurry, could tell, through his photo shoots, how some African people strive their efforts in order to protect their territory. In 2016, a young photographer, Joey L., took the pictures for the new Lavazza calendar, titled From Father to Son. In particular, this calendar talks about those "modern heroes of the Earth" who, thanks to the teaching of their parents, feed on the planet in a sustainable way. This calendar brings to the light the local rituals and traditions of the newest earth defenders, and this is the reason why the calendar is focused on young people, who are the only ones able to connect tradition and innovation without depleting their territory. Finally, the 2017 sees the last calendar of this trilogy, based on the relation between people ant their territory: Whe Are What We Live. In this case the leading people are those living in the Southwest Asia and moving forwards their lives in a symbiotic way with their land. Again, they are seen as heroes.

The ideation and the planning of the last calendar (2018), titled 2030 What Are You Doing?, however, represent a further quantum leap for the roaster, as well as for its stakeholders. This is not more about the analysis and the storytelling of lives, which are involved in the coffee supply chain, but the attention shifts on global 
value environmental and social objectives. These are the so-called Sustainable Development Goals (SDGs), also known as the Global Goals; "a universal call to action to end poverty, protect the planet and ensure that all people enjoy peace and prosperity" (UN, 2015). The peculiarity of these goals is that everybody can do something accordingly, but one isolate action doesn't pay. This is a matter of choral and tangible actions and for involving individuals, communities and firms it is necessary the use of impacting communication tools. Thus the Lavazza Calendar, as renown and popular initiative, becomes one tool for effectively spreading the communication around the SDGs. Accordingly, to introduce such SDGs to the public at large, since apparently these goals are still unknown, Lavazza decided to involve a famous and renown photographer and storyteller, Platon, who could capture the real essence of 17 (as the SDGs are) sustainability leading people. These heroes (as they are called by Lavazza) have been chosen for their particular and personal involvement in one of the 17 SDGs and to give everybody inspiration for the future. The main message is that everyone can be a hero for his/her daily sustainable actions and that everybody should feel involved in reaching the 17 UN goals.

\section{Managerial Implications}

Despite being referred to a peculiar industry, the case provides useful insights replicable in other industries characterized by similar value chains. By analysing already reached goals and those these empowerment initiatives aim at, it is possible to outline a sort of rulebook for corporates which base their sustainability on key stakeholder empowerment and the main suggestions are about to:

- Tailor the projects on the territories and communities actual requirements;

- Advocate first for economic sustainability of the local farmers;

- Train smallholders and local farmers both on processes innovation and private life sustainable behaviour;

- $\quad$ Favour the cooperation and the sharing of practices for innovation of processes in respect to the environment;

- $\quad$ Favour the entrepreneurial capital through advisory;

- Make the social businesses (as outcomes of the projects) autonomous;

- Enhance key stakeholders' relationships with government and institutions;

- Balance the institutional communication between marketing objectives and information goals.

To sum up, the sustainability goals pursued by the Group and its Foundation actions represent an opportunity for creating value: this is a shared value. This is a change of perspective that the whole production chain is called on to assimilate. The business itself, the coffee places and local communities, the consumers, all the coffee players: everything and everyone involved in the coffee industry can take advantage of these sustainable actions and from the fact that sustainability is not something at the side of the business, but it definitively is inside the business itself. 


\section{Bibliography}

Ben Youssef, K., Leicht, T., Pellicelli, M., \& Kitchen, P. J. (2017). The importance of corporate social responsibility (CSR) for branding and business success in small and medium-sized enterprises (SME) in a business-to-distributor (B2D) context. Journal of Strategic Marketing, pp. $1-17$. https://doi.org/10.1080/0965254X.2017.1384038

Brondoni S.M. (2014) Global Capitalism and Sustainable Growth. From Global Products to Network Globalisation, Symphonya. Emerging Issues in Management (symphonya.unimib.it), 1, 10-31.

http://dx.doi.org/10.4468/2014.1.02brondoni

Blowfield M., Dolan C. (2010), Fairtrade Facts and Fancies; What Kenyan Fairtrade tea tell us about Business Role as development agent, Journal of Business ethics, 93, pp. 143-162. http://dx.doi.org/10.1007/s10551-010-0558-2

Cleland, D. (2010). The impacts of coffee production on local producers. http://digitalcommons.calpoly.edu

Mosca, F. \& Civera, C. (2017). The Evolution of CSR: An Integrated Approach, Symphonya. Emerging Issues in Management (symphonya.unimib.it), 1, 16-35.

http://dx.doi.org/10.4468/2017.1.03mosca.civera

Lavazza (2014), Sustainability Report.

Lavazza (2015), Sustainability Report.

Lavazza (2016), Sustainability Report.

Pezet, E. \& Casalegno, C. (2017). Balancing Under and Over Communication in Sustainability, Symphonya. Emerging Issues in Management (symphonya.unimib.it), 1, 95-110.

http://dx.doi.org/10.4468/2017.1.08pezet.casalegno

Potts J. (2003), Building a sustainable coffee sector using market based approaches: the role of multi stakeholder cooperation, ICO.org.

Prato B., Longo R. (2012), Empowerment of poor rural people through initiatives in agriculture and natural resource management, OECD.

http://dx.doi.org/10.1787/9789264168350-5-en

Upendranadh, C., \& Subbaiah, C. A. (2012). Small Growers and Coffee Marketing-Issues and Perspective from the Field. Centre for Development Studies.

Valkila J., Haaparane P., Niemi N. (2010). Empowering Coffee straders? The coffee value chain from Nicaragua Fair Trade Farmers to Finnish Consumers, Journal of Busines Eethics, 97, pp. 257-270.

http://dx.doi.org/10.1007/s10551-010-0508-z

Visser, W. (2012). The Future of CSR: Towards Transformative CSR, or CSR 2.0. Kaleidoscope Futures Paper Series, 1. http://dx.doi.org/10.2139/ssrn.2208101

Watson, K., \& Achinelli, M. L. (2008). Context and contingency: the coffee crisis for conventional small scale coffee farmers in Brazil. The Geographical Journal, 174(3), pp. 223-234.

http://dx.doi.org/10.1111/j.1475-4959.2008.00277.x 